\title{
PROHIBITION ON THE OBLIGATION TO DISCLOSE ONE'S WORLDVIEW, RELIGIOUS BELIEFS, OR RELIGION IN THE LIGHT OF ARTICLE 53(7) OF THE CONSTITUTION OF THE REPUBLIC OF POLAND OF APRIL 2, 1997
}

\begin{abstract}
The aim of this article is to present the normative content of article 53 clause 7 of the Constitution of the Republic of Poland of 2nd April 1997. The paper presents the subjective scope of the regulation, including the scope of subjects who enjoy the guarantee of the "right to silence" as well as the list of addressees of the prohibition. The analysis also presents the subjective scope of article 53 paragraph 7 of the Constitution, together with an indication of the legal problems that occur in the practice of law in the context of obligations to respect the "right to silence". The research includes substantive and formal assessment of the legal provision in question.

Keywords: Constitution of the Republic of Poland, right to silence, disclosure of worldview, religious belief, freedom of conscience and religion.
\end{abstract}

\section{General remarks}

Data on somebody's view of the world are the crucial subject of special legal protection in the age of the information society. It should be remembered that in a democratic state governed by the rule of law, a person's view of the world and his or her attitude towards the phenomenon of religion must be regarded as the private sphere of everyone. Information concerning a person's worldview should be legally irrelevant to the activities of public authorities because of the prohibiting of discrimination adopted in Polish law. This is indicated by the words of the preamble to the Constitution of the Republic of Poland of 2 April $1997^{1}$ (hereinafter: Constitution) - "(..) both believers in God (...) and those who do not share this faith (...) are equal in rights and duties towards the common good - Poland (...)". 


\section{Michat Oźóg}

The above statements were developed in the normative part of the Constitution, especially in article 32 of the Constitution, which expresses the principle of equality before the law and the prohibiting of discrimination for any reason.

In accordance with Article 53 (7) of the Constitution, public authorities may not require disclosure of information concerning one's worldview, religious beliefs, or religion. Already at this point it should be strongly emphasised that the normative content of Article 53(7) of the Constitution cannot be understood as prohibiting expression of one's own beliefs, since everyone may manifest their views, which follows from a number of other legal provisions of the Constitution, including: article 53(1-2) (freedom of conscience and religion), 54(1) (freedom of expression), article 57 (freedom of assembly), article 58(1) (freedom of association), article 63 (freedom of petition), and article 73 (freedom of creation, research, and teaching) (Winczorek, 2008). Of course, there is no barrier to any interested person who wants voluntarily to express his or her views before a public authority. The constitutional principle of ideological impartiality (neutrality) of public authorities in article 25 Paragraph 2 of the Constitution has been combined with the right to express religious and ideological beliefs and philosophy in public life (Ożóg, 2015a). The task of the legislator is to provide an effective system of protection against forcing people to reveal information about their beliefs to public authorities. The legal regulation is called in the literature the "right to silence" (Olszówka, 2016; Winczorek, 2008). It is worth mentioning that the above phrase is also an expression of legal language, not only doctrinal, since Article 2, paragraph 5 of the Act of 17 May 1989 on Guarantees of Freedom of Conscience and Religion provides explicitly that citizens may "remain silent in matters of their religion or beliefs" 2 . The legal provision of Article 53(7) and Article 53(6) of the Constitution designates the so-called negative aspect of freedom of conscience and religion (Krukowski, 2005).

The legal literature on the subject pays little attention to the above matters, which is evidenced by the lack of studies discussing the title issue in a broader perspective. Scientific reflections in this area are undertaken to a narrow extent in commentaries to the Constitution; some of them don't include analysis at all, and sometimes they occur only on the margins of other studies. The subject of the research conducted in the scope of article 53 of the Constitution usually concerns the positive aspect of freedom of conscience and religion, including the problematic realization of specific rights mentioned in article 53 par. 2 of the Constitution. In the meantime, the issue of the negative aspect of freedom of conscience and religion deserves 
more attention, especially in the context of increasingly high standards for personal data protection in the era of the information society.

There is no doubt that information about a person's worldview, faith, or religious beliefs constitutes sensitive personal data which requires the highest level of protection against compulsory disclosure to public authorities (Leszczyński, 2014). Obviously, this type of data cannot be obligatorily externalized to private entities either. The complexity of the issue of revealing information about one's worldview, faith, or religious beliefs requires, however, narrowing the research field of this article to vertical relations (public authority - individual), because such legal relations are covered by the scope of article 53 (7) of the Constitution.

In this paper a dogmatic analysis of the provision of article $53(7)$ of the Constitution was undertaken together with the presentation of selected legal problems occurring in legislative and administrative practice along with a proposal of their solution. In the search for the high standard of protection of individual rights in Polish law, reference is made to the jurisprudence of the European Court of Human Rights concerning the issue of "the right to silence". It is also an attempt to assess to what extent the constitutional standard of Article 53 par. 7 of the Constitution is being respected in legal practice, and to answer the question about the need for a possible strengthening of legal guarantees of the "right to silence" at the level of statutory acts.

\section{Linguistic phrases - "worldview," "religious beliefs," "religion"}

The phrases in Article 53 (7) of the Constitution used to define the scope of beliefs that public authorities may not oblige anyone to disclose should be criticized. The phrases "worldview", "religious belief" and "religion" do not create a logical division meeting the criteria of completeness and separability. The term worldview means "a set of one's views about the world and about life, influencing one's behavior" (term worldview - pol. światopogląd, https://sjp.pwn.pl/sjp/swiatopoglad;2528240.html, access: July 30, 2021). The phrase worldview is thus very broad and includes the other terms "religion" and "religious belief" within its scope (Olszówka, 2016). Therefore, the editorial version of the prohibition could simply refer to worldview, which would be sufficient. In addition, it is worth mentioning that the terms "religion" and "religious belief" are in a crossed relationship. One might be tempted to point out the differences in meaning between the expressions "religious belief" and "faith". The presumption of the rationale of the leg- 


\section{Michat Oźóg}

islation is based on the prohibition of synonymous interpretation, i.e. the directive that different phrases of a legal text cannot not be given the same meaning (Morawski, 2006). The meaning of the phrase "religious conviction" should be clarified by explaining the word "conviction", which means "certainty about the rightness of something, an educated opinion about something; conviction" (term conviction - pol. przekonania, https://sjp.pl/ przekonania, access: August 2, 2021). Thus, "religious convictions" refer to the sphere of confessional views. The meaning of the word "confession" is further explained in a separate point (Ożóg, 2015 b).

The phrase "confession" can be taken in linguistic, religious studies, and legal and juridical terms. It is vital to explain the content of this term. As is well known, linguistic interpretation has the most important meaning in the interpretation of laws. Etymologically, the word "religion" means to define somebody's view of the surrounding reality. In dictionary terms it is "a clear formulation of beliefs concerning a given field; a public pronouncement of one's beliefs" (eds: Skorupka, H. Auderska, Z. Łempicka, 1989). The above definition leads us to a conclusion about the very wide range of meaning of this word, because it includes both religious and non-religious beliefs. However, it should be remembered that in everyday language we can meet the use of this word to describe a lifestyle, someone's attitude. The term "creed" means that it is "a statement in which someone professes something" (Term faith, pol. wyznanie https://sjp.pwn.pl/sjp/wyznanie;254 1325.html, access: August 3, 2021).

In determining the meaning of the term "faith", it is worth presenting the religious point of view. In this field of knowledge, the term "denomination" is narrower than the word "religion" and denotes a community forming a faction of a given religion, e.g. Christianity as a Roman Catholic religion and denomination, the Orthodox Church, etc. (Chyliński, 1969). However, it can be noticed that in everyday language the terms "religion" and "denomination" are used quite often as synonyms and the above difference is not exposed.

The phrase "religion" is an expression from a legal act, so we can also distinguish the legal meaning. The word "religion" occurs in many acts of Polish law, and for example, we can point to the Constitution - article 48, paragraph 1, sentence 2 in fine; article 233, paragraph 2; the provisions and title of the Act of May 17, 1989 on guarantees of freedom of conscience and religion; the title of chapter XXIV of the Act of June 6, 1997 - the Criminal Code - "crimes against freedom of conscience and religion" 3 . The Act of 9 August 2019 on the National Population and Housing Census $2021^{4}$ in Annex No. 1 in section 6 "ethno-cultural characteristics" defines "re- 
ligion" as "belonging to a church or religious denomination". Of course, the above definition was prepared for the purposes of this law, as part of conducting a population and housing census. This cannot be regarded as the universal definition of the term "religion" in Polish law. Thus, in no way can its validity be recognized on the grounds of other social relations, including in particular with regard to the interpretation of constitutional regulation. It should be borne in mind that constitutional concepts have an autonomous character and meaning, and it is inadmissible to interpret them through the prism of statutory regulation (Judgment of the Constitutional Tribunal of 7 February 2001, ref. no. K 27/00), LEX no. 46367). By the way it is worth noting here the difference in this issue in relation to an analogous legal regulation from 10 years ago, when the previous census was conducted. Article 2.12 of the Act of 4 March 2010 on the National Census of Population and Housing $2011^{5}$ stipulated that whenever this act refers to "religion - religious affiliation - it shall be understood as the formal participation or emotional connection of a person with a particular religious denomination, church, or religious association". The mentioned definition clearly emphasizes the religious aspect of expression, focusing on an individual's relationship with a particular religious structure. Perhaps the change in the legislature's attitude stems from a recognition of the difficulty in defining what an unclear "emotional connection" is. It is worth pointing out that so far, these are the only normative attempts to define the term "religion" that have been made by the Polish legislature. At this point, it is also worth noting that filling out the questionnaire regarding one's religion is optional for everyone, as evidenced by the choice of option no. 3 - "I do not want to answer this question".

Moreover, the term "religion" is an expression of legal language, as it is the subject of scientific research in legal studies. In the study of constitutional law and religious denomination law, the term "religion" is considered to be a "positivist" concept, in contrast to the concept of "religion", which is found in international human rights law (Krukowski, Warchałowski, 2000). Underlying the above assumption is the fact that the phrase "freedom of thought, conscience, and religion" appears in international human rights acts. The translation has caused a problem in Polish legal acts: one of the words used in international law acts is religion, which literally means "religion" in Polish. However, the Polish legislature translated the phrase religion as faith/confession rather than religion in the Polish language, which may come as a surprise. This could probably be due to the strong attachment to the formula "freedom of faith/confession" in the Polish legal tradition. 


\section{Michat Oźóg}

The above reflections lead to the conclusion that no matter which meaning of the term "religion" is adopted in the interpretation of Article 53 par. 7 of the Constitution, it will always include within its scope of designations the phrase "worldview", which has the broadest scope. Consequently, it seems that the prohibition of Article 53(7) of the Constitution should concern the obligation to disclose worldview in genere, as this is the widest, most adequate formula and covers the other two elements mentioned in the legal provision. Trying to understand the intentions of the legislature in the adopted enumeration in art. 53 par. 7 of the Constitution may presume that the enumeration was aimed at emphasizing those spheres about which public authorities are prohibited from asking anyone (Olszówka, 2016).

\section{The personal scope}

By the personal scope of the regulation in Article 53(7) of the Constitution, I mean the determination of two issues: first, for whom the legal provision provides the legal guarantees contained therein, saying in other words, whom it protects; and second, who is the addressee of this legal norm. The normative content of the provision of Article 53(7) of the Constitution begins with the phrase "nobody". This is a negative pronoun, meaning "the nonexistence of a person with the properties specified in the given sentence". The phrase "nobody" implies the assumption of a maximally wide range of beneficiaries of a given constitutional right or freedom. Its equivalent is the phrase "everyone" used in the positive definition of the list of subjects of a given right or freedom (Zubik, 2007). It follows unequivocally from the content of Article 53 par. 7 of the Constitution that the legal guarantees are provided for everyone, irrespective of any differentiating criteria. The scope of legal protection covers all categories of persons - Polish citizens, foreigners, as well as stateless persons. The same coverage should be provided for citizens from European Union countries, as well as for persons from other countries. The mentioned right, as well as all others within the scope of freedom of conscience and religion, constitutes the personal freedom of a person. When discussing the subjective scope of the prohibition in article 53 par. 7 of the Constitution, it should be emphasized that the source of constitutional rights and freedoms in Polish law is human dignity (art. 30 Constitution), which is inherent and inalienable (Mazurek, 1996). Such an anchoring of human rights means a rejection of the positivistic concept in the understanding of constitutional rights and freedoms. In fact, Polish law unambiguously advocates the legal-natural concept of human rights (Gar- 
licki, 2003). Thus, the freedom in article 53 of the Constitution, including the prohibition against obliging anyone to denounce their worldview, religious beliefs or religion, is not a manifestation of the legislature's blessing, but only a confirmation of inherent and inalienable human rights.

The scope of protection of the guarantee in Article 53 par. 7 of the Constitution also includes children. In Polish law, the definition of a child has been adopted in article 2, paragraph 1 of the Act of 6 January 2000 on the Children's Rights Ombudsman ${ }^{6}$, in which it was determined that a child is a human being from conception to adulthood. This means that public authorities in their contacts with children may not formulate any questions about their religion, beliefs, or religious beliefs. It would also be impermissible to ask such questions of the child's parents. It should be remembered that children should be treated in the same way as adults in this matter. It is worth mentioning that the legal status of a child under Article 53(7) of the Constitution is not affected by the legal relationship between the child and its parents. On the other hand, there may be a situation in which the parents themselves, as part of exercising their right to raise a child in accordance with their own convictions (Article 48(1) and Article 53(3) of the Constitution), may voluntarily disclose the child's worldview. It is particularly important that the making of such statements is always fully free.

A grammatical interpretation of Article 53(7) of the Constitution leads to the conclusion that it bans public authorities from obliging anyone to disclose information about their worldview, religious beliefs, or religion. The result of the literal interpretation, however, is unacceptable because it permits imposing an obligation to disclose another person's beliefs to a public authority. At the same time, there is no doubt that these authorities are not allowed to ask such questions. This follows first of all from the content of Article 51 Section 2 of the Constitution. Having the above in mind, the directives of systematic and purposive interpretation should be applied in decoding the normative content of Article 53 Paragraph 7 of the Constitution. The above findings lead to the conclusion that public authorities may not oblige any person to disclose somebody's worldview, religious beliefs, or religion. What's more, it seems that the assumption of the regulation in Article 53 (7) of the Constitution is the crucial need to protect the weaker party of the legal relationship - the individual in his relations with the public authority, so it is legally irrelevant whose beliefs are to be revealed.

As was mentioned, the prohibition of Article 53(7) of the Constitution concerns the protection of all natural persons. In accordance with Polish jurisprudence, the constitutional rights and freedoms are not intended for public authorities (Constitutional Court Decision: of 26 october 2001, 


\section{Michat Oźóg}

Ts 72/01; of 6 February 2001, Ts 188/00; of 6 February 2001, Ts 148/00; of 20 December 2007. SK 67/05). In accordance with Article 25 clause 2 of the Constitution, the organs of public authority are obliged to respect ideological impartiality (neutrality) in issues of ideological, religious, and philosophical beliefs. On the other hand, it is obvious that the holders of these bodies have their own beliefs like any other human being and enjoy the rights arising from both aspects of freedom of conscience and religion. Of course, a public authority cannot oblige a hub of another public authority to disclose its worldview, religious beliefs, or religion precisely because of Article 53(7) of the Constitution.

It seems that in certain cases it may be difficult to provide protection of the individual's freedom of conscience and religion together with compliance with the requirement of worldview impartiality of the public authority. This problem relates in particular to decision-making by persons sitting on collegiate legislative bodies, as it is not uncommon to have to vote on broadly defined ideological matters when issuing various categories of acts. It seems, that a member of such a body, e.g. a councillor or parliamentarian, may not expect the vote to be kept secret by invoking the protection of the individual under Article 53(7) of the Constitution. The legal considerations for secret ballots are clearly described in legal regulations and constitute an exception to the principle of public voting, which is in accordance with the principle of openness of public life set forth in Article 61 of the Constitution. It should be stated that the protection of the worldview beliefs of members of legislative bodies is not provided in Polish law as a basis for secret voting. There is also the issue of determining whether each vote reveals the beliefs of the voter, and whether there can be said to be an obligation to declare an opinion on a given matter. In practice, there was a legal problem of admissibility of secret voting on the opinion on the motion to place a cross in the conference room of the town hall in Kędzierzyn-Koźle. The Opole Voivode, using his supervisory entitlement, revoked the resolution, stating that there were no grounds for a secret ballot in this matter and found a violation of Art. 14 of the Act of 8 March 1990 on municipal self-government ${ }^{7}$. In turn, the Supreme Administrative Court stated that a resolution of this type is not a "declaration of worldview" but is only a "resolution of public administration" and voting on these issues does not have to mean disclosure of the councillor's worldview (Judgment of the Supreme Administrative Court of 12 March 2013, ref. no. I OSK 1997/12. sygn. akt I OSK 1997/12). The court held that "casting a vote by a councillor on the placement of a symbol (even a religious one) in public space can hardly be regarded as an unequivocal declaration of worldview". W. Brzozowski disagreed with the 
above thesis, stating that "in practice, participation in such a vote assumes - and without a shadow of a doubt - a preference for a particular conception of the place and role of religion in the state"; however, the vote in this matter was not imposed, but constituted a decision of the legislative body (Brzozowski, 2015). In conclusion, it seems that a person holding public office enjoys, in certain situations, a lower standard of protection of various constitutional rights and freedoms. It should be stated that the openness of public life is a cornerstone of democracy, voting on matters of opinion sensu stricto should indeed be avoided, and if necessary, voters should be given a free choice of religious and philosophical beliefs. On the other hand, the hubs of these bodies have their own beliefs like any other human being and enjoy the rights arising from both aspects of freedom of conscience and religion. Of course, a public authority cannot oblige a holder of another public authority to disclose its worldview, religious beliefs, or religion, precisely because of Article 53(7) of the Constitution.

Candidates for a body of public authority may not be obliged to take an oath or pledge in a particular worldview. This follows primarily from the need to respect Article 53(7) of the Constitution. For these reasons, the voluntariness of the phrase "so help me God" in the words of the oath should be fully appreciated: The oaths of office of the President of the Republic of Poland (Article 130 of the Constitution), parliamentarians (Article 104 of the Constitution), the Prime Minister, the Vice-President of the Council of Ministers, a minister (Article 151 of the Constitution).

In the Polish legal system there are pre-war legal regulations, which raise doubts as to the content of article 53 paragraph 7 of the Constitution. Namely, the provisions of Articles 9, 11, 19 of the Act of 21 April 1936 on the Relationship of the State to the Muslim Religious Union in the Republic of Poland ${ }^{8}$ impose an obligation to take a religious oath before taking up elected posts. The Mufti takes the oath before the President (art. 9), members of the Supreme Muslim College and their deputies before the governor or his deputy (art. 11), imams and muezzins before the district governor or his deputy (art. 19). The provisions are anachronistic and do not take into account the current systemic model of relations between the state and religious communities (Borecki, 2014).

It is worth mentioning that in the judgment of the European Court of Human Rights in the case Alexandridis v. Greece of 21 February 2008 (Judgment of the European Court of Human Rights in Alexandridis v. Greece of 21 February 2008 Application No. 19516/06), a violation of Article 9 of the European Convention for the Protection of Human Rights and Fundamental Freedoms ${ }^{9}$ was recognized in the case of the existence of one version 


\section{Michat Oźóg}

of the religious oath in the Orthodox denomination, the taking of which was mandatory for taking the position of a lawyer before the Court of First Instance of Athens. In contrast, in the Buscarini and Others v. San Marino judgment of 18 February 1999, the Grand Chamber of the Court stated that there had been a violation of Article 9 because of the requirement to take an oath on Scripture before taking the mandate of a parliamentarian (Judgment of the Grand Chamber of the European Court of Human Rights in Buscarini and Others v. San Marino, 18 February 1999, Application No. 24645/94). The Court strongly emphasized that the mandate implies representation of all worldview systems.

The subjective scope of Article 53 (7) of the Constitution does not include organizational units, which is due to the specificity of the "right to silence". The worldview is an attribute of natural persons. Legal persons, organizational entities with legal capacity, or other institutional structures are created by people for the realization of various goals and do not possess independent beliefs of their own. All structures are always created by specific people. It is theoretically possible to imagine a situation in which a public authority officially questions the governing bodies of a structure about the position of that organization in a dispute over worldview or a controversial issue. Of course these individuals then enjoy the legal protection provided for natural persons in Article 53(7) of the Constitution, although they then speak on behalf of the organizational unit. The realization of the right to silence by an individual thus affects, in a sense, the status of the organizational structure.

Determination of the addressee of the prohibition in Article 53(7) of the Constitution requires clarification of the notion of public authority. It should be assumed that these are the organs of legislative, executive and judicial power, as well as all other entities that may in a sovereign manner shape the rights and obligations of external subjects. These will also include organs of professional and economic self-government, to the extent that they have public authority power (Winczorek, 2008). These may also be private entities that perform public tasks on the basis of an appropriate agreement. The concept of public authority in Article 53(7) of the Constitution should be understood as broadly as possible in order to encompass the legal protection of individuals in their relations with all entities that exercise public authority. Such an interpretation is based on concern for the legal protection of the weaker party to the legal relationship.

Linguistic interpretation of the provision of Article 53(7) of the Constitution leads to the conclusion that the notion of public authority does not directly include employees of public entities who perform public tasks. 
It must be stated that this is a very broad category of subjects. It may be pointed out that these can be employees of various administrative establishments: medical entities, educational institutions, cultural centers, museums, detention centers, prisons, social welfare homes, etc. In the above-mentioned units there is usually one managerial body (sometimes more), which can be undoubtedly considered a public authority in the strict sense, and the remaining personnel form the circle of employees of the entity carrying out public tasks. It seems, however, that also in this case the provision of Article 53 (7) of the Constitution should be interpreted taking into account the ratio legis, considering all employees of public entities as the addressees of the prohibition in this legal provision, in order to prevent the possibility of imposing on individuals the obligation to disclose their worldview, religious beliefs or religion (Compare: Supreme Court judgment of September 20, 2013, II CSK 1/13, Lex No. 1388592).

It should be stated that the scope of addressees of the application of this legal norm does not include private entities, which do not have authority and power over the individual. This issue has already been noted in the introduction to this article. In cases of compulsion by a private entity to disclose one's worldview, religious beliefs, or religion, it should be assumed that legal protection against such inquiries arises from the normative content of Article 47 (the right to protection of private life) and Article 51(1) of the Constitution, which provides that "no one shall be obliged otherwise than by law to disclose information concerning his person". For example, it may be indicated that a private employer during the recruitment process may not ask about the worldview matters of a candidate for a given job position.

\section{Material scope}

The provision of Article 53(7) of the Constitution stipulates that no one may be obliged to disclose his worldview, religious beliefs, or religion, which requires a detailed explanation of the meaning of the individual phrases forming the disposition of the legal provision.

The obligation referred to in this legal provision means the imposition of a requirement to provide information about one's worldview, religious beliefs, or religion. The necessity to provide the above information may be formulated in many ways: in writing - e.g. in an official form, the expectation of a written declaration - or also in an oral form, during a conversation with a representative of public authority. It is unacceptable to apply pres- 


\section{Michat Oźóg}

sure or coercion to make such statements or to expect the tacit admission of a suggested worldview. Violation of the norm founded in Article 53 par. 7 of the Constitution occurs also when no legal consequences are foreseen for failure to disclose somebody's worldview or for disclosing the worldview of a certain content by an individual. It should be emphasized that the legislator protects the individual in the legal provision in question both from the very asking of such questions, as well as from bearing the possible consequences of refusing to answer them. These could be sanctions resulting directly from the provisions of law, including those of a criminal or administrative law nature. It would be inadmissible to make the resolution of a case dependent on the disclosure of such information.

For the above reasons, the question of practicing the Roman Catholic religion and the expectation of submitting the appropriate certificate, which was to be requested by the common court in Myślenice may be regarded as a controversial. The case is not known to the author, but only from media reports (https://tvn24.pl/krakow/sad-zada-zaswiadczenia-o-byciu-praktyku jacym-katolikiem-ra601459-3320341, access: July 31, 2021). The fundamental issue will be whether the content of Article 53(7) of the Constitution is absolute. The doctrinal views on this issue are divided. One may note the view that the content of Article 53(7) of the Constitution constitutes a rule and may not be subject to limitations and thus it may be implemented "either in its entirety or not at all" (Florczak-Wątor, 2014). However, the opposite view assumes that the "right to silence" is subject to the general principles of limitations of constitutional rights and freedoms from Article 31 (3) of the Constitution (Olszówka, 2016). It is worth mentioning that this was also the opinion of the Constitutional Court, which did not share the position that the limitation clause of freedom in Article 53 of the Constitution cannot be applied to «freedom from interference» (Judgment of the Constitutional Court of 7 October 2015, K 12/14, paragraph III 7.1.3). In turn, in the judgment of the Constitutional Tribunal of 11 May 2007 (ref. no. K 2/07), it was stated that "the latter constitutional provision (Article 53, para. 7 - author's reminder) refers to the prohibition to oblige one to disclose one's worldview, religious beliefs, or religion, and there are no convincing arguments in favour of limiting the constitutional right specified in this provision due to the justified purposes of the contested law (the law of 18 October 2006. on disclosing information on documents of state security bodies from the years 1944-1990 and the content of such documents ${ }^{10}$ - author's remark - Paragraph 15. 1. of the justification to the judgment of the Constitutional Tribunal of 11 May 2007, ref. no. K 2/07. It is worth mentioning that the 
Constitutional Tribunal stated that a certain extent of article 22 paragraph (3) point (2) of the lustration act was inconsistent with article 53(7) of the Constitution.

I share the Constitutional Tribunal's view on the relative nature of Article 53(7) of the Constitution. First of all, it must be recognized that freedom of conscience and religion is not an absolute right and may be subject to limitations. Only the freedom of conscience in its internal aspect is of an absolute character. However, it should be stated that recognition of someone's rights in accordance with one's convictions in social relations may already be restricted in certain situations. Applying the above findings to the assessment of the above case, it must be assumed that the court's request to submit a certificate that a particular religion is being practised is inconsistent with Article 53(7) of the Constitution if the requirement to submit the certificate is mandatory for the party. In addition, it is worth noting that a clergyman is not a public administrative body in a state separated from religious communities; there is no question in this case of performing public tasks or functions of authority, so the certification of the circumstances of the practice of religion appears unfounded and the connection with the case at hand is not known. Information concerning someone's religion or worldview should be indifferent for public authorities. It is also worth noting at this point that a mandatory requirement to take an oath with a religious connotation in court is impermissible and would constitute a violation of Article 53(7) of the Constitution. In the judgment of 3 June 2013 in Dimitras and Others v. Greece, a violation of Articles 9 and 13 of the Convention was found in relation to a provision of the Greek Criminal Code which imposed an obligation in criminal proceedings to take an oath with the right hand placed on the Bible, while the defendants informed the court that they were not "orthodox Christians" (Judgment of the European Court of Human Rights in the case of Dimitras and Others of 3 June 2013, Application No. 34207/08, 6365/09).

The problem of presentation of certificates of a person's approach to religion may also apply to other entities that act under the authority of the state and performing certain public tasks. The requirement to provide a certificate of religious observance was the subject of dispute in relation to M.J.'s admission to postgraduate studies "environmental protection policy - ecology and management" at the Higher School of Social and Media Culture in Torun. That institution is run by an ecclesiastical body, but it issues diplomas of completion of studies which are recognised by the State. What's more, these studies were co-financed with public funds. M.J. did not provide the required document from his parish priest stating that he prac- 


\section{Michat Oźóg}

tices Roman Catholicism, because he described himself as a non-believer. As a result, he was not accepted to the studies. The case was very complex and also concerned the admissibility of judicial-administrative review of a refusal of admission to postgraduate studies from the perspective of the subject-matter jurisdiction of an administrative court (Cf. decision of the Supreme Administrative Court of 17 April 2018, ref. I OSK 929/18, https://orzeczenia.nsa.gov.pl/doc/157A08408E.). The main problem of this case concerned the issue of whether a university run by a church entity could demand compliance with this obligation from candidates for studies. The civil court awarded M. J. damages in the amount of PLN 5,000 (Chmielewska, 2021). From the point of view of the title considerations, it is worth considering whether the provision of Article 53 Section 7 of the Constitution should apply in this case. It seems that each higher education institution that receives public authority, i.e. conferring professional titles and academic degrees, does so on the authority of the state, and in this sense may be regarded as a public authority within the meaning of Article 3 Section 7 of the Constitution. The same should be stated in the case of financing studies in whole or in part from public funds. This is all justified because of the fact that in the case of financing studies from public funds - Polish or European - access to education should be provided on equal terms for all interested persons, regardless of the criterion of religion. What's more, the formulation of questions about religion and the expectation to submit certificates of religious practice should not take place in the current circumstances. It appears that the above does not change the profile of the research and teaching unit, nor the principle of the autonomy of churches and other denominational organisations in Article 25(3) of the Constitution, if the studies are co-financed from public funds. It should be remembered that the implementation of the principle of the autonomy of churches and denominational organisations, just like other constitutional principles, requires consideration of the boundaries that arise from the overall provisions of the Constitution. It seems that if the university bodies did not issue diplomas recognised by the state, then they would not constitute organs of public authority. Denominational schools that are financed fully by the religious communities' own funds, e.g. from contributions or offerings, may restrict access to education to adherents of their own religious group by imposing confessional requirements, e.g. about practicing a religion with confirmation of this circumstance by an appropriate certificate.

It seems, however, that in some cases revealing any information about worldviews can be helpful to resolving litigation. One example is worth pointing out. We can imagine a conflict between parents over the direction 
of their children's religious upbringing in a situation where they represent different worldview systems. The pluralism of worldviews makes it likely that more and more disputes will arise over the implementation of the parents' right to raise their child according to their own beliefs (article 48 of the Constitution). From my point of view, the guardianship court, hearing a case under Art. $97 \S 2$ of the Act of 25 February 1964 - the Family and Guardianship Code ${ }^{11}$ - may ask the parents a question concerning, for example, the form of marriage, whether it was a religious form with civil effects, because the above circumstance may provide some guidance in deciding the merits of the case (Ożóg, 2020, p. 43). However, it is inadmissible to ask directly about the religion of the child's mother or father.

Among the frequent misunderstandings concerning the misinterpretation of article 53 par. 7 of the Constitution are situations where an individual makes a declaration of will to exercise one of the specific rights within the scope of freedom of conscience and religion. The provision of article 53 par. 7 of the Constitution is most often considered in the literature on the subject precisely in the context of making a declaration by parents about their child's participation in religious instruction in a public school. Referring to the above dispute, it should be mentioned that parents are not forced to reveal their beliefs or those of his or her child. However, it should be a shared doctrinal view that it would be more appropriate for such statements to be collected by representatives of religious communities that organize religious instruction, and not by the management of an educational institution or public authorities (Pietrzak, 2010). It should also be pointed out that in order to exercise one's constitutional right to participate in catechesis, one must externalise one's wish in some way. For this reason the prohibition in Article 53(7) of the Constitution cannot be understood as a prohibition on voluntary declaration of participation of a child in religious instruction. Nor is it at all obvious that the person who is to attend religious instruction is also an adherent of a particular faith, for there is no such requirement. It is just a statement regarding attendance at a religious lesson, which anyone can attend.

It is worth presenting another example of a situation. The practice of asking questions about a patient's wish to receive pastoral care should be approached in a similar way. Article 36 of the Act of 6 November 2008 on Patient Rights and Patient Ombudsman ${ }^{12}$ obliges medical entities to provide pastoral care to all interested persons. On admission to hospital, the question should be asked as concisely and generally as possible (Ożóg, 2018). Obviously, it is not permitted to ask directly whether one belongs to a particular religious community or denomination. The patient, in response to 


\section{Michat Oźóg}

the general question, should voluntarily ask for contact with a clergyman of a particular religion or another person offering pastoral care. However, this must be done with respect for the rights of persons who do not wish to exercise the right in article 36 of the Act, as this statement, also supported by article 53, paragraphs 1 and 6 of the Constitution. The court cases indicate that information about the approach to world-view issues at the time of admission to a hospital can, on the one hand, help to realize the wishes of believers and possibly their families in order to avoid possible disappointment with the failure to provide pastoral care in life-threatening conditions (Judgment of the Court of Appeal in Lublin of 17 October 2012, ref. no. I Acz 690/12, http://orzeczenia.lublin.sa.gov.pl/content/\$N/153000 000000503_I_ACa_000420_2012_Uz_2012-10-17_001), as well as to respect the views of non-believers and thus not to initiate pastoral care ex officio (Judgment of the Supreme Court of September 20, 2013, II CSK 1/13, Lex No. 1388592). This requires knowledge of the wishes of the patient or his family. Article 53(7) of the Constitution must be read in conjunction with other provisions of the constitutional law regulations, including Article 53(2), second sentence in fine, which provides for the right of everyone to receive religious assistance wherever he/she is, thus also in a medical facility, and with Article 53(7) and (6), which protect against the imposition of pastoral care.

It must be remembered that public authorities may not make the exercise of specific rights in the area of freedom of conscience and religion conditional on the person concerned proving that he or she belongs to a particular religious association. It would be good to present one case concerning this issue. In one of the cases related to protection of personal rights of a convicted person, there was a problem with realization of a specific right within the scope of freedom of conscience and religion of the convicted person, i.e. manifestation of religion by beard. In the judgment of the Court of Appeal in Kraków of 24 April 2018 (ref. no. I ACa 1217/17) it was stated that "The plaintiff failed to prove the fundamental circumstance for the case, i.e. the violation of his personal rights, related to his right to profess a religion (...) and act in accordance with its principles. In this regard, he failed to prove a fundamental fact, namely that he was actually a follower of this religion during his stay in the Penitentiary Institution in N. (hereinafter: ZK"). It should be emphasized that the demand of the penitentiary administration body for the prisoner to prove his affiliation to a particular religious community was entirely without legal basis, which is a violation of Article 53(7) of the Constitution (Ożóg, 2020). Undoubtedly, the administrative bodies of the penitentiary units, as well as the Penitentiary Court, the Dis- 
trict Court and the Court of Appeal are organs of public authority within the meaning of Article 53(7) of the Constitution. It must be clearly stated that proof of membership in a given religious community is not a prerequisite for the protection of freedom of conscience in Polish law and therefore cannot be required on the grounds of civil law protection of freedom of conscience. It is possible to imagine a situation in which someone is even formally excluded from the confessional denomination by an act of clerical authority, has converted, and the public authorities of a worldview-impartial state cannot assess such conduct, which must remain legally irrelevant. Legal provisions may provide that a given entitlement of freedom of conscience and religion shall be reserved only for churches and religious associations with a regulated legal status - the opportunity to participate in religion at school (art. 53 (4) Constitution), the possibility to enter into a religious marriage with civil effects Article $1 \S 2$ and 3 of the Act of 25 February 1964 - Family and Guardianship Code, and, even if this is so regulated, in such cases the public authorities may not verify whether the person exercising the entitlement remains a member of a religious community (Ożóg, 2020).

Public authorities cannot demand the expression of somebody's worldview, religious beliefs, or religion in official documents, including identity cards. The judgment of the European Court of Human Rights Sinan Işık v. Turkey of 2 February 2010 (Judgment of the European Court of Human Rights Sinan Işlk v. Turkey, 2 February 2010) unequivocally accepted that the presence of the rubric "religion" in an identity card is a violation of Article 9 of the Convention and it is irrelevant whether the disclosure of this circumstance is compulsory or voluntary. It is worth mentioning that the "right to silence" at the statutory level was implemented in Polish law in the Decree of 25 September $1945^{13}$, the Law on Civil Status Records, in which the item "religion" was deleted from all official documents (Leszczyński, 2014). The column "religion" was also removed by the ordinance of the Minister of Public Administration and Regained Territories of November 15, $1947^{14}$, on the change Decree of the Minister of the Interior on registration and population registers. A breakthrough was the repeal of the partition regulations that regulated the duties of citizens in connection with a change of religion, and were formally derogated by the decree of 5 September 1947 on the regulation of the legal status of the EvangelicalReformed Church in the Republic of Poland, the Mariavite Church and the Old Catholic Church ${ }^{15}$.

At this point I would like to briefly refer to the idea of introducing the institution of a tax assessment or church tax in the Polish law, which perhaps will return to Polish public discussion in the future. It worth mentioning this 


\section{Michat Oźóg}

issue in the perspective of the normative content of Article 53 (7). In my opinion, the issue of the rubric with the declaration of religious affiliation has not only an "organizational-technical and human" character and meaning, but also a constitutional one in the light of Article 53 par. 7 of the Constitution. However, a contrary statement is also found in the science of law (Leszczyński, 2014). It must not be forgotten that technical acts can affect the status of the individual. The method of solving technical issues - in my opinion - should be subject to the assessment of the constitutionality of the legal regulation, in the scope in which this "organisational and technical" activity finds legal consequences for the individual in the light of Article 53 par. 7 of the Constitution. The technical aspect of the way in which personal information is collected is crucial nowadays.

The proposed possibility of making a tax deduction of $0.3 \%$ of the income of a personal income taxpayer was the subject of legal analyses that were published in the Public Information Bulletin of the Ministry of Administration and Digitization (Leszczyński, 2014). The normative content of Article 53 paragraph 7 of the Constitution seems to be problematic from the point of view of the introduction of this solution. First of all, it necessary to point out the differences between these legal institutions. Church tax, based on the German model (German - Kirchensteuer) is obligatory and assumes that an appropriate fraction of the taxpayer's income will be transferred to the religious community to which the taxpayer belongs in order to maintain the needs and activities of the community (Stanisławski, 2014). This requires obtaining information on the confessional affiliation of the taxpayer, so the tax document must contain a "religion" column. It should be pointed out that the literature expresses the view that the introduction of the institution of a church tax into Polish law is hindered precisely because of Article 53 paragraph 7 of the Constitution (Stanisz, 2008). In this matter, a problem may arise as to the constitutionality of such a solution due to the lack of voluntariness of making such a declaration, as well as due to the question of direct affiliation to a religious structure in the public documents. In this context it is worth mentioning the judgment of the European Court of Human Rights in the case of Wasmuth v. Germany of 17 February 2011 (Judgment of the European Court of Human Rights in Wasmuth v. Germany of 17 February 2011, Application No. 12884/03), in which it was found that the entry «" - "» in the column «"deductible church tax"», does not constitute a violation of Articles 8 and 9 of the Convention. The European Court of Human Rights accepted that the interference with the applicant's rights was legally justified by the objective of providing churches and religious associations with the option of collecting a church tax. What is more, 
the requirement of proportionality of the interference to the aim was fulfilled in view of the low importance of the information about non-affiliation with a religious community which the tax authorities obtain. The jurisprudence of the Strasbourg Convention and the case law of the European Court of Human Rights radiate into Polish law, so that the recognition of the church tax as legally permissible on the basis of the Convention may encourage reflection on the understanding of the meaning of Article 53(7) of the Constitution in the context of the discussion on the legal aspects of the model of financing religious communities in Poland. The specificity of the jurisprudence of the European Court of Human Rights should of course be taken into account.

It seems that the legal situation would be different in the case of the introduction of the institution of tax signatures, well-known for example in the Italian tax legal system, because this system assumes a voluntary tax deduction for specific purposes of the religious community or for the activities of public authorities, listed in the law (Stanisz, Ordon, 2019). The literature points out that this institution corresponds to the Polish model of relations between the state and religious denominations (Stanisz, 2008). However, it would be necessary to respect the highest standards with regard to the declaration of income donation to a particular religious community and, in particular, to anonymize the taxpayer in a way that is as technically feasible as possible.

\section{Final conclusions}

Article 53(7) of the Constitution is an important guarantee of freedom of conscience and religion in Polish law. This provision gives protection by prohibiting discrimination against a person on the grounds of belief. It seems that the linguistic deficiencies may be corrected in the future. First of all, the normative content of Article 53 (7) of the Constitution should synthetically define the prohibition of obligatory disclosure of beliefs in genere. In terms of substance, this provision fully respects the standards of protection of the individual against constraint in matters of worldview. It does not seem necessary to formulate additional legal regulations in this respect in the statutory acts. In my opinion, expecting such norms would mean in fact repetition of the prohibition of Article 53 par. 7 of the Constitution in other formulations for the needs of different social relations, which misses the point. The regulation in Article 5(2) of the Act of 17 May 1989 on Guarantees of Freedom of Conscience and Religion is sufficient. Certainly, 


\section{Michat Oźóg}

it is possible to prohibit certain practices that constitute a violation against Article 53 Paragraph 7 of the Constitution in laws from different areas of social life, which specify detailed issues, but this seems to be a difficult and risky procedure. The risk results from the fact that the casuistry of regulation may lead to overlooking a certain area, and this will lead to negative consequences. It seems that the most problematic issues that arise in respect of compliance with Article 53(7) of the Constitution require factual actions, above all sensitizing the legislature as well as the entities applying the law to the validity of this legal provision. Persons working in the public sector who have relations with external entities should be well acquainted with constitutional human and civil rights and freedoms. Awareness of human rights should be put on a higher level. It is worth noting that respecting this provision of Article 53(7) of the Constitution also contributes to respecting the Polish legislature's approach to the accepted place of the phenomenon of religiousness in public life. Article 53(7) of the Constitution should always be understood as a human right to silence and not as an injunction to silence, and for this it is necessary to respect the requirement of the worldview impartiality of the organs of public authority. Of course, it is possible to amend the Constitution in this issue and modify the disposition of the norm in Article 53(7) of the Constitution; however, this provision should be preserved in the structure of Article 53 of the Constitution, as it provides an important guarantee of freedom of conscience and religion in the era of the information society.

\section{N O T E S}

1 Journal of Laws 1997, No. 78, item 483.

2 Consolidated text Journal of Laws 2017, item 1153.

3 Consolidated text Journals of Laws 2021, item 1023.

4 Journals of Laws 2019, item 1775.

5 Journal of Laws Dz.U. z 2011 r. Nr 47, poz. 277.

6 Consolidated text Journals of Laws 2020, item 141.

7 Consolidated text Journals of Laws 2021, item 1038.

8 Journals of Laws 1936, No. 30, item 240.

9 Journals of Laws 1993, No. 1993, No. 61, item 284.

10 Journal of Laws 2006, No. 218, item 1592.

11 Consolidated text Journals of Laws 2020, item 1359.

12 Consolidated text Journals of Laws 2020, item 849.

13 Journals of Laws 1945, No. 48, item 272.

14 Journals of Laws 1948, No. 2, item 7. 
Judgment of the Constitutional Tribunal of 7 February 2001, (ref. no. K 27/00), LEX no. 46367.

Judgment of the Constitutional Tribunal of 11 May 2007, ref. no. K 2/07.

Judgment of the Constitutional Tribunal of 7 October 2015, K 12/14.

Constitutional Court Decision of 6 February 2001, Ts 148/00.

Constitutional Court Decision of 26 October 2001, ref. no. Ts 72/01.

Constitutional Court Decision of 6 February 2001, ref. no. Ts 188/00.

Constitutional Court Decision of 6 February 2001, Ts 148/00.

Constitutional Court Decision of 20 December 2007, ref. no. SK 67/05.

Judgment of the Supreme Court of September 20, 2013, II CSK 1/13, Lex No. 1388592.

Judgment of the Supreme Administrative Court of 12 March 2013, ref. no. I OSK 1997/12, ref. no. I OSK 1997/12.

Decision of the Supreme Administrative Court of 17 April 2018, ref. I OSK 929/18, https://orzeczenia.nsa.gov.pl/doc/157A08408E.

Judgment of the Court of Appeal in Lublin of 17 October 2012, ref. no. I Acz 690/12, http://orzeczenia.lublin.sa.gov.pl/content/\$N/153000000000503_I_ACa_000420_2012_Uz_ 2012-10-17_001.

Judgment of the Grand Chamber of the European Court of Human Rights in Buscarini and Others v. San Marino, 18 February 1999, Application No. 24645/94.

Judgment of the European Court of Human Rights in Alexandridis v. Greece of 21 February 2008 Application No. 19516/06.

Judgment of the European Court of Human Rights in Wasmuth v. Germany of 17 February 2011, Application No. 12884/03.

Judgment of the European Court of Human Rights in the case of Dimitras and Others of 3 June 2013, Application No. 34207/08, 6365/09.

Judgment of the European Court of Human Rights Sinan Işıkv. Turkey, 2 February 2010.

\section{R E F E R E N C E S}

Borecki, P. (2014). Prawodawstwo wyznaniowe z okresu II Rzeczypospolitej we współczesnym polskim systemie prawnym. Studia Prawa Publicznego, 8.

Brzozowski, W. (2013). Glosa do wyroku NSA z dnia 12 marca 2013 r., I OSK 1997/12. Zeszyty Naukowe Sadownictwa Administracyjnego, 5; on-line version: https://sip.lex.pl/\#/publication/386060487/brzozowski-wojciech-glosado-wyroku-nsa-z-dnia-12-marca-2013-r-i-osk-1997-12?cm=URELATIONS (access: August 2, 2021).

Chmielewska, M. (2021). Szkoła medialna o. Rydzyka zapłacita odszkodowanie. Marek Jopp będzie ponownie studentem?. https://tylkotorun.pl/szkola-me dialna-o-rydzyka-zaplacila-odszkodowanie-marek-jopp-bedzie-ponownie-stu dentem/, access: August 3, 2021.

Chyliński, H. (1969). In: Z. Poniatowski (eds.), Mały słownik religioznawczy. Warszawa. 


\section{Michat Oźóg}

Florczak-Wątor, M. (2014). Horyzontalny wymiar praw konstytucyjnych. Kraków.

Garlicki, L. (2003). Komentarz do art. 30. In: L. Garlicki (ed.), Konstytucja Rzeczypospolitej Polskiej. Komentarz. Tom III. Warszawa.

Krukowski, J. (2005). Polskie prawo wyznaniowe, Warszawa.

Krukowski, J. Warchałowski, K. (2000). Polskie prawo wyznaniowe. Warszawa.

Leszczyński, P. A. (2014). Prawo do nieujawniania światopogladu, przekonań religijnych lub wyznania. In A. Mezglewski (ed.), Leksykon prawa wyznaniowego. 100 podstawowych pojęć. Warszawa.

Mazurek, F. J. (1996). Pojęcie godności człowieka. Historia i miejsce w projektach Konstytucji III Rzeczypospolitej. Roczniki Nauk Prawnych KUL, 6.

Morawski, L. (2006). Wstęp do prawoznawstwa. Torun.

Olszówka, M. (2016). Komentarz do art. 53. In M. Safjan, L. Bosek (eds.), Konstytucja RP. Tom I. Komentarz. Art. 1-86. Warszawa.

Ożóg M., Dyskryminacja w realizacji prawa rodziców do wychowania dziecka zgodnie z własnymi przekonaniami. In: P. Sobczyk (ed.), Prawna ochrona wolności sumienia i religii. Stan de lege lata oraz postulaty de lege ferenda, Warszawa 2020

Ożóg, M. (2015 a). Regulować czy deregulować swobodę wyrażania przekonań w życiu publicznym? Rozważania na tle art. 25 ust. 2 Konstytucji Rzeczypospolitej Polskiej z 2.4.1997 r. Przeglad Prawa Wyznaniowego, 7.

Ożóg, M. (2015 b). Wolność sumienia i religii w stanach nadzwyczajnych w polskim systemie prawnym, Forum Prawnicze, 2.

Ożóg, M. (2018). Postawa pracowników podmiotów leczniczych w kontekście realizacji prawa pacjenta do opieki duszpasterskiej w Polsce. Przeglad Prawa Wyznaniowego, 10.

Ożóg, M. (2020). Glosa do wyroku Sądu Apelacyjnego w Krakowie z dnia 24 kwietnia 2018 roku, (ref. I ACa 1217/17). Przeglad Prawa Wyznaniowego, 2020.

Pietrzak, M. (2010). Prawo wyznaniowe. Warszawa.

Stanisławski, T. (2014). Podatek kościelny. In: A. Mezglewski (ed.), Leksykon prawa wyznaniowego. 100 podstawowych pojęć. Warszawa.

Stanisz P. (2008). Finansowanie kościołów $i$ innych zwiazzków wyznaniowych. In Prawo wyznaniowe, A. Mezglewski, H. Misztal, P. Stanisz, Warszawa.

Stanisz P., Ordon M., (2019). Finansowanie związków wyznaniowych w Republice Włoskiej: zarządzanie środkami z asygnaty podatkowej (otto per mille) przedmiotem krytyki Trybunału Obrachunkowego. Studia z Prawa Wyznaniowego, 22.

Term conviction, pol. przekonania, https://sjp.pl/przekonania, access: August 2, 2021.

Term faith, pol. wyznanie. Https://sjp.pwn.pl/sjp/wyznanie;2541325.html, access: august 3, 2021. $32021 \mathrm{r}$. 
Term faith, pol. wyznanie. 1989. In: S. Skorupka, H. Auderska, Z. Łempicka (eds.), Maty stownik języka polskiego. Warszawa.

Term nobody, pol. nikt. Https://sjp.pwn.pl/slowniki/nikt.html, access: July 30, 2021.

Term worldview - pol. światopogląd, https://sjp.pwn.pl/sjp/swiatopoglad;2528240. html, acccesss: July 30, 2021.

Winczorek, P. (2008). Komentarz do Konstytucji Rzeczypospolitej Polskiej z dnia 2 kwietnia 1997 roku. Warszawa.

Wini, https://tvn24.pl/krakow/sad-zada-zaswiadczenia-o-byciu-praktykujacym-ka tolikiem-ra601459-3320341, access: July 31, 2021.

Zubik, M. (2007). Podmioty konstytucyjnych wolności, praw i obowiazków. Przeglad Legislacyjny 2. Electronic version: https://sip.lex.pl/\#/publication/1510823 91/zubik-marek-podmioty-konstytucyjnych-wolnosci-praw-i-obowiazkow?cm =URELATIONS, (access: August 2, 2021). 